\title{
THE SiLENT ROLE OF CORPORATE THEORY IN THE SUPREME COURT'S CAMPAIGN FINANCE CASES
}

\author{
Stefan J. Padfield"
}

\begin{abstract}
In Citizens United v. Federal Election Commission, a 5-4 majority of the Supreme Court held that corporate political speech could not be regulated on the basis of corporate status alone. In support of that conclusion, the majority characterized corporations as mere "associations of citizens." The dissent, meanwhile, viewed corporations as state-created entities that "differ from natural persons in fundamental ways" and "have been 'effectively delegated responsibility for ensuring society's economic welfare." I have previously argued that these two competing conceptions of the corporation implicate corporate theory, with the majority adopting an aggregate/contractarian view, and the dissent an artificial entity/concession view. Even if one understands Citizens United to be primarily about listeners' rights, this stark contrast of competing theories of the corporation is difficult to ignore. At the very least, what the majority and dissent thought about corporate speakers was relevant to deciding whether the campaign finance restrictions challenged in Citizens United should fall within that narrow class of speech restrictions justified on the basis of the speaker's identity due to "an interest in allowing governmental entities to perform their functions." Somewhat surprisingly, however, the majority was silent, and the dissent expressly disavowed, any role for corporate theory. I have also previously offered some explanations for this apparent inconsistency, and concluded that an active "silent corporate theory debate" was indeed integral to the outcome of Citizens United-despite protestations to the contrary. In this Article, I examine the key Supreme Court cases leading up to Citizens United to see whether a similar silent corporate theory debate is evident in those cases. I find that there is indeed such an on-going debate, and proceed to argue that in future cases involving the rights of corporations, the Justices should make their views regarding the proper theory of the corporation express. This will allow for a more meaningful discussion of the merits of those decisions, and impose an additional layer of intellectual accountability on the jurists.
\end{abstract}

* Associate Professor, University of Akron School of Law. B.A., Brown University; J.D., University of Kansas. This Article was presented at the Midwest Corporate Law Scholars Conference on June 15, 2011; a faculty workshop at the University of Dayton School of Law on October 11, 2011; the Central States Law Schools Association Scholarship Conference on October 29, 2011; a faculty workshop at the University of Akron School of Law on February 22, 2012; and the Law and Society Association Annual Meeting on June 8, 2012. My thanks to all the participants for their helpful comments. Particular thanks also to Stephen Bainbridge for his comments on the relationship between the directorprimacy and real-entity theories of the corporation. 
TABLE OF CONTENTS

I. INTRODUCTION

II. A BRIEF OVERVIEW OF THE THEORIES OF THE

CORPORATION

A. The Entity, Contract, and Process Theories of the

Corporation.

B. Concession and Nexus-of-Contracts Theory

III. THE ROLE OF CORPORATE THEORY IN THE SUPREME

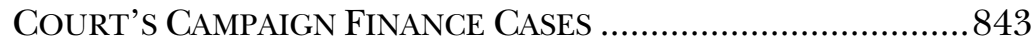

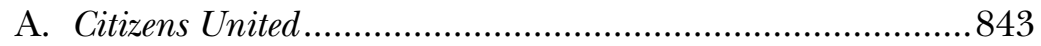

B. The Cases Leading Up to Citizens United .........................848

IV. JUdGing CORPORATIONS POST-CITIZENS UNITED ..................857

V. CRITICISMS OF CORPORATE THEORY'S RELEVANCE .................860

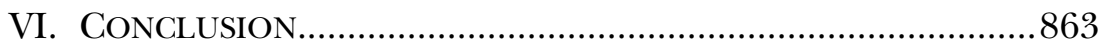

\section{INTRODUCTION}

In Citizens United v. Federal Election Commission, a 5-4 majority of the Supreme Court ruled that corporate political speech could not be regulated on the basis of corporate status alone. ${ }^{1}$ Given that there is a great deal of debate about what corporations are (corporations have to date eluded capture), one would think that the Court would have needed to answer that question first before reaching its conclusion. However, the majority was silent on this issue and the dissent went so far as to expressly disavow any role for corporate theory at all. ${ }^{2}$ Instead, the opinion appeared to rest on a "listeners' rights" analysis. ${ }^{3}$ It remains unclear, however, how focusing on

1130 S. Ct. 876, 913 (2010) ("[T] he Government may not suppress political speech on the basis of the speaker's corporate identity.”).

$2 \quad I d$. at 971 n.72 (Stevens, J., dissenting in part and concurring in part) ("Nothing in this analysis turns on whether the corporation is conceptualized as a grantee of a state concession, ... a nexus of explicit and implicit contracts, ... a mediated hierarchy of stakeholders, ... or any other recognized model." (internal citations omitted)).

3 See Larry E. Ribstein, The First Amendment and Corporate Governance, 27 GA. ST. U. L. REv. 1019, 1052-53 (2011) (discussing implications of a listeners' rights rationale of Citizens United). But see First Nat'l Bank of Bos. v. Bellotti, 435 U.S. 765, 828 (1978) (Rehnquist, J., dissenting) ("It is true ... that recent decisions of this Court have emphasized the interest of the public in receiving the information offered by the speaker seeking protection. The free flow of information is in no way diminished by the Commonwealth's decision to 
listeners' rights could eliminate all need to examine the nature of corporations. ${ }^{4}$ For example, how would one know whether corporations fit within the well-established line of identity-based exception cases under the First Amendment without addressing the unique aspects of corporate identity? ${ }^{5}$ As I have previously noted:

[The fact that] corporations could pursue goals that no individual living human being desired (and that might in fact be harmful to human beings) because the relevant decision-makers were legally required to follow the dictates of a fictional shareholder, could implicate the question of whether corporations should fall within that narrow class of speech restrictions justified on the basis of identity due to "an interest in allowing governmental entities to perform their functions."

The Court in Citizens United simply rejected any such contention by baldly asserting that: "The corporate independent expenditures at issue in this case, however, would not interfere with governmental functions."

Despite protestations to the contrary, however, a closer reading of the Citizens United opinion reveals that both the majority and dissent not only adopted diverging theories of the corporation, but that those theories were likely dispositive. I have previously set forth my arguments in support of this

permit the operation of business corporations with limited rights of political expression. All natural persons, who owe their existence to a higher sovereign than the Commonwealth, remain as free as before to engage in political activity."). Cf. TAMARA R. Piety, Brandishing the First Amendment: Commercial EXPRESSION IN AMERICA 18 (2012) (noting that Virginia State Board of Pharmacy v. Virginia Citizens Consumer Council, Inc., 425 U.S. 748 (1976) (creating the commercial speech doctrine), "was also novel because it focused on the listeners' (consumers') rights to hear rather than on the speakers' (pharmacies') right to speak").

4 Cf. Anne Tucker, Flawed Assumptions: A Corporate Law Analysis of Free Speech and Corporate Personhood in Citizens United, 61 CASE W. RES. L. ReV. 497, 511 (2011) ("The [Massachusetts Citizens For Life] Court, however, used the marketplace-of-ideas metaphor as a general justification to restrict corporate speech, not as a means to strike down the regulation for the benefit of the citizen-listeners as it had in past cases." (citing Fed. Election Comm'n v. Mass. Citizens for Life, Inc., 479 U.S. 238, 257 (1986) ("This concern over the corrosive influence of concentrated corporate wealth reflects the conviction that it is important to protect the integrity of the marketplace of political ideas."))).

5 Citizens United, 130 S. Ct. at 899 ("The Court has upheld a narrow class of speech restrictions that operate to the disadvantage of certain persons ....").

6 Stefan J. Padfield, The Dodd-Frank Corporation: More Than a Nexus-Of-Contracts, 114 W. VA. L. REV. 209, 227-28 (2011) (footnote omitted) (quoting Citizens United, 130 S. Ct. at 899) [hereinafter Padfield, The Dodd-Frank Corporation]. See also Citizens United, 130 S. Ct. at 972 (Stevens, J., dissenting in part and concurring in part) ("Perhaps the officers or directors of the corporation have the best claim to be the ones speaking, except their fiduciary duties generally prohibit them from using corporate funds for personal ends.... It is entirely possible that the corporation's electoral message will conflict with their personal convictions."); Tucker, supra note 4, at 536 ("A second, broader criticism of the Court's assumptions regarding the singular corporate voice and freedom of association is that corporate speech does not reflect the view of any citizen-shareholder . ...").

7 Citizens United, 130 S. Ct. at 899. 
proposition elsewhere, and will repeat them here to the extent necessary in Part III.A. ${ }^{8}$ Obviously, understanding the Court to have based its decision on a "covert" application of corporate theory raises a number of interesting questions. First, why not simply engage in this analysis overtly? Second, if the Court engaged in a silent corporate theory analysis in Citizens United, was that the first time it had done so or is this part of some larger trend? Finally, how should we respond to this practice, if in fact it is one? I will attempt to answer these questions in this Article.

Following this Introduction, I will set forth a brief overview of the relevant theories of the corporation. In Part III, I will examine the role of corporate theory in some of the Supreme Court's most important campaign finance cases. First, in Part III.A, I will explain how corporate theory was dispositive in Citizens United. Next, in Part III.B, I will examine the key Supreme Court cases leading up to Citizens United. I will argue that corporate theory played the same silent and dispositive role in many of those cases as it did in Citizens United.

In Part IV, I will discuss the implications of my conclusions. Ultimately, I will argue that the Justices of the Supreme Court should make express their views about what constitutes the best theory of the corporation. This will allow for better analysis and criticism of the Court's opinions in this area. While there remains some possibility that this practice would not alter the ultimate results in at least some of these cases, it is difficult to argue that the increased transparency and accountability would be a bad thing. Furthermore, as I will strive to make clear in the pages that follow, as between the two primary theories of the corporation, one essentially precludes the possibility of reaching Citizens United's conclusion that political speech rights may not be regulated on the basis of corporate status alone, and the other is practically necessary to reach that result. In light of this, the Court's failure to discuss corporate theory in Citizens United (beyond Justice Stevens' unconvincing attempt to sweep the issue aside in a footnote) constitutes a material omission that should be corrected in future opinions

8 This Article extends my previous work on Citizens United and the theory of the corporation. See Stefan J. Padfield, Citizens United and the Nexus-of-Contracts Presumption, 1 HARV. BuS. L. REV. ONLINE 25, 26 (2011), http://www.hblr.org/2011/01/citizens-unitedand-the-nexus-of-contracts-presumption/ [hereinafter Padfield, Citizens United and the Nexus-of-Contracts Presumption] (arguing that the competing visions of the corporation advanced by the majority and dissent in Citizens United roughly aligned with two divergent theories of the corporation-"nexus-of-contracts theory for the majority and concession theory for the dissent"); Padfield, The Dodd-Frank Corporation, supra note 6 (arguing that Dodd-Frank's official recognition of the too-big-to-fail corporation undermined the majority's opinion in Citizens United because that opinion rested on a theory of the corporation that espouses a worldview wherein deregulated markets lead to an efficient allocation of assets, not global crisis). 
addressing the role of corporations in society. Nonetheless, I do address some potential criticisms of my proposal in Part V. Finally, I provide concluding remarks in Part VI.

\section{A BRIEF OVERVIEW OF THE THEORIES OF THE CORPORATION}

Robert Hamilton and Richard Booth identify the primary theories of the corporation as: (1) entity theory; (2) concession theory; (3) contract theory; (4) nexus-of-contracts theory (also known as contractarianism); and, (5) "process" theory. ${ }^{9}$ As I will explain in more detail below, Hamilton's and Booth's process theory can be understood to capture both the directorprimacy and team-production theories of the corporation. ${ }^{10}$ One should also understand that concession theory and "artificial entity" theory are essentially synonymous, as are nexus-of-contracts theory and "aggregate" theory. Finally, I will also argue that director-primacy/team-production theory and "real entity" theory are synonymous. ${ }^{11}$ Because this may all be a bit overwhelming for the uninitiated, I offer the following table for assistance. The reader should take comfort in knowing that at the end of this section we will predominantly be focusing on only two of these theories: concession and nexus-of-contracts.

9 Robert W. HAMilton \& Richard A. BOOTH, Black LetTER OUTLINES: CORPORATIONS 327-32 (5th ed. 2006) (detailing the various theories of corporation law).

10 See generally Stephen M. Bainbridge, Director Primacy: The Means and Ends of Corporate Governance, 97 NW. U. L. REV. 547 (2003) (describing the director primacy model as it relates to various aspects of corporation law); Margaret M. Blair \& Lynn A. Stout, A Team Production Theory of Corporate Law, 85 VA. L. REV. 247 (1999) (arguing for a mediating hierarchy model as a solution to problems inherent in public corporations).

11 As will be discussed in more detail below, both my alignment of director-primacy/teamproduction with real entity theory, and my conclusion that real entity theory had less of a role to play in Citizens United v. Federal Election Commission, 130 S. Ct. 876 (2010), than the contractarianism and concession theory, are at least somewhat controversial. 


\begin{tabular}{|c|c|c|c|}
\hline $\begin{array}{l}\text { THEORY OF THE } \\
\text { CORPORATION }\end{array}$ & $\begin{array}{l}\text { ALTERNATIVE } \\
\text { DESIGNATION }\end{array}$ & BRIEF DESCRIPTION & $\begin{array}{c}\text { RELEVANT TO } \\
\text { OUTCOME IN CITIZENS } \\
\text { UNITED? }\end{array}$ \\
\hline Entity & & $\begin{array}{l}\text { The corporation is a } \\
\text { separate legal entity } \\
\text { that can, for exam- } \\
\text { ple, sue and be } \\
\text { sued. }\end{array}$ & No. \\
\hline Concession & $\begin{array}{l}\text { Artificial } \\
\text { Entity }\end{array}$ & $\begin{array}{l}\text { The corporation is a } \\
\text { creature of the state } \\
\text { intended to benefit } \\
\text { society as a whole. }\end{array}$ & $\begin{array}{l}\text { Yes. The theory posits } \\
\text { that the state has wide } \\
\text { latitude in regulating } \\
\text { its creation. }\end{array}$ \\
\hline Contract & & $\begin{array}{l}\text { The corporate char- } \\
\text { ter represents a con- } \\
\text { tract between the } \\
\text { state and incorpora- } \\
\text { tors. }\end{array}$ & No. \\
\hline $\begin{array}{l}\text { Nexus-of-contracts } \\
\text { (Contractarianism) }\end{array}$ & Aggregate & $\begin{array}{l}\text { The corporation is a } \\
\text { creature of private } \\
\text { contracting. }\end{array}$ & $\begin{array}{l}\text { Yes. The theory posits } \\
\text { that the state merely } \\
\text { provides default rules } \\
\text { to facilitate private } \\
\text { ordering. }\end{array}$ \\
\hline $\begin{array}{l}\text { Director-primacy \& } \\
\text { Team Production } \\
\text { (Process) }\end{array}$ & $\begin{array}{l}\text { Real (Natu- } \\
\text { ral) Entity }{ }^{12}\end{array}$ & $\begin{array}{l}\text { The corporate locus } \\
\text { of control resides in } \\
\text { the board of direc- } \\
\text { tors, which focuses } \\
\text { on coordinating the } \\
\text { interests of all } \\
\text { stakeholders. }\end{array}$ & $\begin{array}{l}\text { Perhaps, but arguably } \\
\text { less so than contrac- } \\
\text { tarianism and conces- } \\
\text { sion theory. }\end{array}$ \\
\hline
\end{tabular}

I will first briefly review entity theory, contract theory, and process theory (including director-primacy and team-production theory), before moving on to a more detailed overview of concession theory and nexus-of-contracts

12 See Darrell A.H. Miller, Guns, Inc.: Citizens United, McDonald, and the Future of Corporate Constitutional Rights, 86 N.Y.U. L. REV. 887, 914 n.174 (2011) ("The real entity theory is also known as the natural entity theory."). 
theory. I do this because I believe the entity, contract, and process theories have more limited roles to play in terms of their influence on the campaign finance cases I discuss herein, while the concession and nexus-of-contracts theories represent the two "preeminent" theories of the corporation. ${ }^{13}$

\section{A. The Entity, Contract, and Process Theories of the Corporation}

Entity theory simply posits that the corporation is indeed a separate legal entity capable, for example, of being sued and filing suit against others in its own name. ${ }^{14}$ This is to be contrasted with businesses operating in the general partnership form where, at least traditionally, the partnership was viewed as nothing more than an aggregation of the individual owners. ${ }^{15}$ Indeed, it is the fact that the corporation stands as a separate legal entity between the owners and third parties that provides at least part of the justification for bestowing limited liability upon the owners. ${ }^{16}$ As compared to concession theory and nexus-of-contracts theory, however, the fact that the corporation is deemed a legal entity with the right to sue and be sued tells us little about where to draw the line on the state's authority to regulate corporations.

Contract theory, meanwhile, provides that "the charter of a corporation represents a contract (a) between the state and the corporation, or (b) between the corporation and its stockholders, or (c) among the stockholders." ${ }^{17}$ This theory was most famously relied upon by the Supreme Court in its Dartmouth College decision, wherein the Court held that the State of New Hampshire would violate the Contracts Clause of the United States Constitution if it unilaterally amended the charter of Dartmouth College

13 Liam Séamus O'Melinn, Neither Contract nor Concession: The Public Personality of the Corporation, 74 GEO. WASH. L. REV. 201, 201 (2006) (describing contractarianism and concession theory as "the two preeminent theories of the corporation").

14 HAMilton \& BOоTH, supra note 9, at 327-28 ("A corporation may be most readily envisioned as an entity created for the purpose of conducting a business.... The entity has the power to ... bring[] suits or be[] sued ....").

15 Frederick Mark Gedicks, The Recurring Paradox of Groups in the Liberal State, 2010 UTAH L. REV. 47, 55-56 (2010) ("Because corporations are legal entities, the circumstances in which the law will look past the corporation to its individual owners and managers are limited. Because partnerships are not legal entities, however, the situation is reversed: the circumstances in which the law will look to the partnership as an entity, rather than to its owners and managers, are limited." (footnote omitted)).

16 Thomas C. Folsom, Evaluating Supernatural Law: An Inquiry into the Health of Nations (The Restatement of the Obvious, Part II), 21 Regent U. L. Rev. 105, 148 (2008) ("Limited liability entities are based on the moral intuition of nonagency because there is separation of ownership from control.").

17 HAMilton \& BOоTH, supra note 9, at 329. 
without having reserved the right to do so in the original corporate charter. ${ }^{18}$ It is in this opinion that Justice Marshall also famously stated:

A corporation is an artificial being, invisible, intangible, and existing only in contemplation of law. Being the mere creature of law, it possesses only those properties which the charter of its creation confers upon it, either expressly, or as incidental to its very existence. These are such as are supposed best calculated to effect the object for which it was created.... The objects for which a corporation is created are universally such as the government wishes to promote. They are deemed beneficial to the country; and this benefit constitutes the consideration, and, in most cases, the sole consideration of the grant. ${ }^{19}$

The theory now serves primarily as the justification for the ubiquity of reservation clauses in state corporate codes. ${ }^{20}$ It should also be noted here, and will be discussed in more detail below, that in addition to serving as the flagship opinion for the contract theory of the corporation, the preceding quoted language from Justice Marshall has also been further claimed primarily by concession theorists. ${ }^{21}$

Process theory, meanwhile, views the corporation as "a process by which various inputs of capital, services, and raw materials are combined to produce desirable products." ${ }^{22}$ As alluded to previously, for purposes of this Article, I am equating process theory with both the director-primacy and team-production theories of the corporation. As I have written elsewhere:

$[\mathrm{I}] \mathrm{t}$ appears clear that director primacy and team production theory differ in terms of what they view as the goal of corporate governance. For director primacy, it is shareholder wealth maximization. For team production theory, it is the maximization of "the joint welfare of all the

18 Trs. of Dartmouth Coll. v. Woodward, 17 U.S. 518, 650 (1819) ("The opinion of the Court, after mature deliberation, is, that this [charter] is a contract, the obligation of which cannot be impaired, without violating the constitution of the United States.").

19 Id. at 636-37.

20 See Ian S. Speir, Constitutional and Statutory Reservation Clauses and Constitutional Requirements of General Laws With Respect to Corporations: The Fifty States and the District of Columbia 1 (Apr. 24, 2011), available at http://ssrn.com/abstract=1820868 ("Reservation clauses, reserving to the legislature a power to amend or repeal corporate charters, are included in the constitutions or corporation statutes of 49 states and the District of Columbia."). Cf. Eric W. Orts, Beyond Shareholders: Interpreting Corporate Constituency Statutes, 61 GEO. WASH. L. REv. 14, 69 (1992) ("Advocates of Contract Clause protection for shareholders are aware of the 'reserve' clauses resulting from Dartmouth College, but they appear to underestimate the full import of these powers. States have 'reserved' the freedom ... to 'impair' the rights of shareholders ....”).

21 See Citizens United v. Fed. Election Comm'n, 130 S. Ct. 876, 971 n.72 (Stevens, J., concurring in part and dissenting in part) (citing Dartmouth College as an example of concession theory).

22 HAMilton \& BoоTH, supra note 9, at 332. 
firm's stakeholders." However, both theories locate the ultimate decision-making power in the board of directors . . . ${ }^{23}$

It is precisely because both theories "locate the ultimate decision-making power in the board of directors" that I am equating them with Hamilton's and Booth's process theory. That is to say, the board mediates the process. ${ }^{24}$

Both team-production and director-primacy have been linked to contractarianism. For example, J.W. Verret has noted that:

Margaret Blair and Lynn Stout's team production model... relies on contractarian thinking .... In part the team production theory rests on a conception of the institution of corporate law as a solution for limitations in the ability of corporate constituencies to contract with each other .... [Instead,] the constituencies opt into their "mediating hierarchy" of the board of directors ....

Meanwhile, Stephen Bainbridge, "the leading proponent of the director primacy view," ${ }^{26}$ also clearly aligns director-primacy with the nexus-ofcontracts view. ${ }^{27}$ Nonetheless, the reason why I believe the director-primacy and team-production theories should take a back-seat to concession theory and nexus-of-contracts theory in our discussion here is because even if those theories capture the current state of power allocation within the corporation, the question remains whether this state of affairs is a result of the market contracting for it or the state deeming it so. ${ }^{28}$ In other words, the more fundamental debate between contractarianism (market decides) and concession theory (state decides) remains regardless of what we conclude about the relevant validity of the director-primacy and team-production theories. Furthermore, even if both the team-production and director-

23 Stefan Padfield, Director-Primacy and Team-Production as Real Entity Theories, THERACETOTHEBOTTOM.ORG (June 3, 2012), http://www.theracetothebottom.org/ home/director-primacy-and-team-production-as-real-entity-theories.html.

24 See Blair \& Stout, supra note 10, at 250-51 (1999) ("In essence, the mediating hierarchy solution requires team members to give up important rights ... to a legal entity created by the act of incorporation.... Within the corporation, control over... assets is exercised by an internal hierarchy.... At the peak of this hierarchy sits a board of directors....").

25 J.W. Verret, Treasury, Inc.: How the Bailout Reshapes Corporate Theory and Practice, 27 YALE J. ON REG. 283, 321-22 (2010) (footnotes omitted). See also id. at 317 ("The contractarian model is in many ways a precursor to ... the director primacy model.").

26 Id. at 321

27 See Stephen M. Bainbridge, The Board of Directors as Nexus of Contracts, 88 Iowa L. Rev. 1, 25 (2002) ("If the corporation has a nexus, however, where is it located? The Delaware code, like the corporate law of every other state, gives us a clear answer: the corporation's 'business and affairs... shall be managed by or under the direction of a board of directors.' Put simply, the board is the nexus." (footnote omitted) (quoting Del. Code Ann. tit. 8, §141(a) (2001))).

28 See Padfield, The Dodd-Frank Corporation, supra note 6, at 216 (" $[\mathrm{P}]$ recisely because the board of directors' power comes from the state, [director-primacy] could also be viewed as supporting a concession theory view of the corporation." (footnote omitted)). 
primacy theories do indeed trace their roots back to contractarianism, it still arguably makes more sense to focus on the more fundamental theory of contractarianism (and its conventional sparring partner: concession theory) before analyzing its various offspring. ${ }^{29}$

Thus, while all the theories of the corporation described above can be useful, for purposes of this Article I will be focusing on the competing theories of nexus-of-contracts and concession. As Liam O'Melinn has noted, while "[n]ot all theorists use the language of contract and concession," the two "preeminent" theories of the corporation are the nexus-of-contracts theory and concession theory. ${ }^{30}$

\section{B. Concession and Nexus-of-Contracts Theory}

Hamilton and Booth describe concession theory simply as the theory "that a corporation is a grant or concession from the state." Meanwhile, they describe nexus-of-contracts theory as follows:

Economists have developed a theory of corporateness that permits analysis of the corporation as an economic phenomenon. This theory rejects the notion that the stockholders are the ultimate owners of the enterprise but treats them, along with bondholders and other creditors, as providers of capital in anticipation of receiving a desired return. The nexus of contracts theory assumes that corporate managers obtain the requirements of the corporation for capital, labor, materials, and services through a series of contractual relationships. ${ }^{32}$

29 To some extent, this may all be unnecessary hair-splitting because, as I will attempt to show below, the difference between real-entity theory (where I ultimately locate the teamproduction and director-primacy theories) and contractarianism is potentially inconsequential in terms of the pro-regulatory/anti-regulatory debate because both realentity theory and contractarianism are typically used to justify deregulation in modern discourse.

30 See supra note 13, at 201 \& n.3. See also id. at 258 (discussing "concession theory and ... its nexus of contracts counterpart").

31 HAMilton \& BоOTH, supra note 9 , at 328.

$32 I d$. at 330. See generally Melvin A. Eisenberg, The Conception That the Corporation is a Nexus of Contracts, and the Dual Nature of the Firm, 24 J. CORP. L. 819 (1999) (describing the history and limitations of the nexus of contracts conception).

In 1976 Michael Jensen and William Meckling first formulated the conception that the corporation is a nexus of contracts.... Since that time, the conception has dominated the law-and-economics literature in corporate law.... [T] he intellectual history of ... Jensen and Meckling...begins with Ronald Coase[]... [who] characterized the boundaries of the firm as the range of exchanges over which the market system was superseded and resource allocation was accomplished instead by authority and direction.... Armen Alchian and Harold Demsetz objected to the Coasian conception of the firm, and emphasized instead the role of team production within the firm and the role of agreement and monitoring in team production.... Jensen and Meckling applauded Alchian and Demsetz's objection to Coase's theory of the firm, but concluded that Alchian and Demsetz had not gone far enough in rejecting Coase .... Jensen and Meckling therefore substituted, for Coase's conception of the firm, the competing 
In differentiating these two theories, it may be helpful to refer to what David Millon describes as the three "dimensions" along which corporate theory has evolved: (1) the corporation as a separate entity versus "a mere aggregation of natural individuals without a separate existence"; (2) the corporation as an "artificial creation of state law" versus a "natural product of private initiative"; and (3) the corporation as a public versus a private construct. ${ }^{33}$ One may then align concession theory with a view of the corporation as a distinct, separate entity that is a creature of state law serving an ultimately public function, while nexus-of-contracts theory lines up with a view of the corporation as a mere aggregation of natural individuals that is a product of private initiative serving a predominantly private function. One of the key distinctions flowing from all of this is that concession theory tends to support giving the state greater authority to regulate, while nexus-ofcontracts theory espouses private ordering. Returning to Hamilton and Booth:

According to the nexus of contracts model, it follows that the state should not—and indeed possibly may not—prescribe mandatory rules for corporations by statute that are inconsistent with the express or implicit contracts. The role of corporation statutes, according to this theory, is to provide standardized rules that most corporations will adopt, thereby providing savings for corporations that do not need to incur the cost of independently drafting such provisions. ${ }^{34}$

Some have suggested that concession theory is no longer viable because it is inexorably tied to a time in history when corporate status was bestowed by the states on a case-by-case basis via a special charter system. For example, Henry Butler and Larry Ribstein have written that "[concession] theory had its origin in the early history of the corporation, when corporations were, in fact, created by special charter. The theory has no relevance today, when corporations are freely formed by making a simple filing under general corporation laws. ${ }^{35}$ However, I believe Grant Hayden

conception that the firm was a nexus of contracts-and, more particularly, "that most organizations are simply legal fictions which serve as a nexus for a set of contracting relationships among individuals ...."

Id. at 819-22 (internal footnotes omitted) (quoting Michael C. Jensen \& William H. Meckling, Theory of the Firm: Managerial Behavior, Agency Costs and Ownership Structure, $3 \mathrm{~J}$. FIN. ECON. 305, 310 (1976)) (citing R. H. Coase, The Nature of the Firm, 4 ECONOMICA 386 (1937); Armen A. Alchian \& Harold Demsetz, Production, Information Costs, and Economic Organization, 62 AM. ECON. ReV. 777 (1972)).

33 David Millon, Theories of the Corporation, 1990 DUKE L.J. 201, 201 (1990).

34 HAMilton \& BoOTH, supra note 9, at 330-31.

35 HenRY N. ButLER \& LARRY E. RibSTEIN, THE CORPORATION AND THE CONSTITUTION, at ix (1995). Larry Ribstein unfortunately and prematurely passed away on December 24, 2011. His impact on the legal academy cannot be overstated. For a truly moving collection of remembrances, visit: Geoffrey Manne, Larry Ribstein, RIP, TRUTH ON THE MARKET (Dec. 24, 2011), http://truthonthemarket.com/2011/12/24/larry-ribstein-rip/. 
and Matthew Bodie espouse the better view when they note that: "One cannot contract to form a corporation... The fact that th[e] permission [to incorporate] is readily granted... does not change the fact that permission is required." ${ }^{36}$ As I have written elsewhere:

[Add together] the ubiquity of reserve clauses in corporate codes, the existence of stakeholder statutes, and relatively recent judicial pronouncements that "[c]orporations are creatures of the Legislature... [i]t is appropriate, therefore, that the terms and conditions of their existence be determined by that body," and I would go so far as to label the argument that concession theory is necessarily tied to our special charter era a straw man. ${ }^{37}$

Ultimately, anyone who feels compelled to tie the phrase "concession theory" to our special charter era should feel free to replace it herein with something more generic, like "the state-conferred benefits argument.",38

Finally, and as already alluded to above, it is important to note that constitutional law scholars have tended to use a slightly different lexicon when discussing the role of corporate theory in the Supreme Court's case law. As Reuven Avi-Yonah describes it:

$\mathrm{Th}[\mathrm{e}]$ theories are the aggregate theory, which views the corporation as an aggregate of its members or shareholders; the artificial entity theory, which views the corporation as a creature of the State; and the real entity theory, which views the corporation as neither the sum of its owners nor an extension of the state, but as a separate entity controlled by its managers. ${ }^{39}$

For myself, I noted that, "while there is obviously much in terms of scholarship that Larry is worth remembering for, what I will primarily remember him for is his inspiring kindness." Stefan J. Padfield, The Inspiring Kindness of Larry Ribstein, Business LAW PROF BLOG (Dec. 25, 2011), http://lawprofessors.typepad.com/business_law/2011/12/theinspiring-kindness-of-larry-ribstein.html.

36 Grant M. Hayden \& Matthew T. Bodie, The Uncorporation and the Unraveling of "Nexus of Contracts" Theory, 109 MiCH. L. REv. 1127, 1130 (2011) (footnote omitted). Cf. Margaret M. Blair, The Four Functions of Corporate Personhood 4 (Vanderbilt Univ. Law Sch. Pub. Law \& Legal Theory Working Paper, Paper No. 12-15, 2012), available at http://ssrn.com/abstract=2037356 ("The four functions that legal entity status serve would be very difficult, if not impossible, to accomplish using only transactional contracts.").

37 Padfield, The Dodd-Frank Corporation, supra note 6, at 218 (footnotes omitted) (quoting Neary v. Miltronics Mfg. Servs., Inc., 534 F. Supp. 2d 227, 231 (D.N.H. 2008)) (citing Speir, supra note 20; Orts, supra note 20, at 69).

38 See David G. Yosifon, The Public Choice Problem in Corporate Law: Corporate Social Responsibility After Citizens United, 89 N.C. L. Rev. 1197, 1219 (2011) (discussing "The State-Conferred Benefits Argument"); see also Padfield, The Dodd-Frank Corporation, supra note 6, at 218-20 (rejecting Yosifon's assertion that the state-conferred benefits argument is one of the "'tempting-but-ultimately-bad' argument[s] ... [for] regulating corporate political speech").

39 Reuven S. Avi-Yonah, Citizens United and the Corporate Form, 2010 WIS. L. REV. 999, 1001 (2010) (emphasis added) (footnote omitted). 
As I have also written elsewhere: "[t]he aggregate theory is generally understood to capture the nexus-of-contracts view, the artificial entity theory captures concession theory, and the real entity theory arguably captures the director-primacy [and team-production] view of the corporation." ${ }^{40}$ This last point, that the team-production and director-primacy theories are best aligned with real entity theory (rather than, for example, aggregate theory) is certainly not without its controversy. ${ }^{41}$ However, the director-primacy theory of the corporation has been described as espousing "the view that the maximization of shareholder wealth is the appropriate duty of directors ... [and] that resting authority over corporate decisions with a self-sustaining board of directors is the best way to accomplish that objective," indeed lines up well with real-entity theory, which "represents the most congenial view to corporate management, because it shields management from undue interference from both shareholders and the state." ${ }^{, 3}$

Thus having set the stage in terms of corporate theory, we turn now to the role of these theories in the Supreme Court's campaign finance cases. I will first examine the blockbuster Citizens United decision, followed by an analysis of the key Supreme Court precedents leading up to that decision.

\section{THE ROLE OF CORPORATE THEORY IN THE SUPREME COURT'S CAMPAIGN FINANCE CASES}

\section{A. Citizens United}

Citizens United involved a challenge to a federal statute, the Bipartisan Campaign Reform Act of 2002, which prohibited "corporations and unions from using their general treasury funds to make independent expenditures for speech defined as an 'electioneering communication' or for speech

40 Padfield, The Dodd-Frank Corporation, supra note 6, at 215 (footnotes omitted).

41 Stephen Bainbridge rejects my argument that director-primacy theory is best aligned with real entity theory. For a summary of our multi-blog post discussion of the issue, see http:/ /www.theracetothebottom.org/home/the-silent-role-of-corporate-theory-in-thesupreme-courts-ca-3.html. Stefan Padfield, The Silent Rule of Corporate Theory in the Supreme Court's Campaign Finance Cases (Part 4), THERACETOTHEBotTOM.org (Apr. 7, 2012, 5:46 PM), http://www.theracetothebottom.org/home/the-silent-role-of-corporate-theory-inthe-supreme-courts-ca-3.html. On the other hand, Lynn Stout responded to my blog post entitled, Director-Primacy and Team-Production as Real Entity Theories, THERACETOTHEBOtTOM.ORG (June 3, 2012, 9:09 AM), http://www.theracetothebottom.org/home/director-primacy-and-team-production-asreal-entity-theories.html, with an e-mail asserting that my description of the issue was "as well put as I've seen it." E-mail from Professor Lynn Stout to author (June 3, 2012) (on file with author). Cf. Blair \& Stout, supra note 10.

42 Verret, supra note 25, at 321 (identifying Stephen Bainbridge as "the leading proponent of the director primacy view").

43 Avi-Yonah, supra note 39, at 1032. 
expressly advocating the election or defeat of a candidate." ${ }^{44}$ The Supreme Court held, among other things, that the First Amendment prohibits the government from regulating the political speech of corporations on the basis of their corporate identity. ${ }^{45}$ In doing so, the majority relied on a view of the corporation as fundamentally an "association[] of citizens." ${ }^{46}$ The dissent of Justice Stevens, meanwhile, saw corporations as state-created entities that: (1) "differ from natural persons in fundamental ways"; (2) "have no consciences, no beliefs, no feelings, no thoughts, no desires"; and (3) "must engage the political process in instrumental terms if they are to maximize shareholder value." Of particular note, the dissent asserted that "corporations have been "effectively delegated responsibility for ensuring society's economic welfare." ${ }^{50}$

Despite the foregoing, Avi-Yonah has argued that Citizens United does not in fact embody any corporate theory dispute because both the majority and dissent embraced real-entity theory, while merely disagreeing on the application of that theory to the facts of the case. ${ }^{51}$ As I have argued elsewhere, this contention is unpersuasive for at least three reasons. ${ }^{52}$ First,

44 Citizens United v. Fed. Election Comm'n, 130 S. Ct. 876, 886 (2010) (citing 2 U.S.C. $\S 441 \mathrm{~b}$ (2002)). See Tucker, supra note 4, at 512-13.

Following Buckley, the Court in Bellotti similarly rejected the equalization and antidistortion rationales [for regulating corporate political speech] as being unsupported by the record. Instead of rejecting the rationales wholesale, the Court emphasized the lack of a record justifying the restriction. Alerted to the need to develop a record regarding distortion harms to support expenditure limits, Congress did so in passing the Bipartisan Campaign Reform Act. Those restrictions were subsequently recognized as valid in MCFL and Austin.

$I d$. (emphasis in original) (citations omitted).

45 Citizens United, 130 S. Ct. at 885 ("Government may not suppress political speech based on the speaker's corporate identity.”) (overruling Austin v. Mich. State Chamber of Commerce, 494 U.S. 652 (1990)).

46 See, e.g., Citizens United, 130 S. Ct. at 906-07 (asserting that the Court's prior ruling in Austin "permits the Government to ban the political speech of millions of associations of citizens"); $i d$. at 908 (asserting that under the challenged statute "certain disfavored associations of citizens-those that have taken on the corporate form-are penalized for engaging in ... political speech").

47 Id. at 971-72 n.72 (Stevens, J., concurring in part and dissenting in part).

$48 \quad$ Id. at 972

49 Id. at 965 .

50 Id. at 971 (quoting Milton C. Regan Jr., Corporate Speech and Civic Virtue, in Debating Democracy's Discontent: Essays on American Politics, LaW, AND PUblic Philosophy 289, 302 (Anita L. Allen \& Milton C. Regan Jr. eds., 1998)).

51 Avi-Yonah, supra note 39, at 1040 ("What is remarkable about Citizens United . . is that both the majority and the dissent adopted the real entity view of the corporation, so that their only disagreement was in divergent assessments of the implications for the First Amendment."). Cf. Tucker, supra note 4, at 505 ("The majority in Citizens United employed both the aggregation-of-rights and entity theory of corporations to reach its conclusion that corporate political speech is to be treated the same as individual political speech.”).

52 See Padfield, The Dodd-Frank Corporation, supra note 6, at 224-26. 
the majority's emphasis on corporation-as-association-of-citizens is consistent with the rhetoric of prior judicial opinions that Avi-Yonah himself identifies as espousing the aggregate (i.e., contractarian) view. ${ }^{53}$ Second, Avi-Yonah's suggestion that "association-of-citizens" in Citizens United should be equated with "corporate management working together as an association of persons" because to equate it with the aggregate view would be to align the majority opinion with the shareholder rights argument the majority rejected is belied by the fact that (a) when the government argues that its regulations should be upheld in order to protect shareholders, it is typically best understood as advancing a concession theory argument and thus, "to reject the state's argument here is to reject concession theory, not the aggregate view, ${ }^{, 54}$ and (b) such a narrow interpretation of "association of citizens" is inconsistent with the much broader use of that phrase in similar contexts by Justice Scalia, whose concurring opinion Avi-Yonah focuses on in making his "association of managers" argument. ${ }^{55}$ Finally, as far as the dissent is concerned, suffice it to say that I am not alone in seeing concession theory jumping off the pages. Stephen Bainbridge entitled one of his blog posts following the release of the opinion, "Stevens' Pernicious Version of the Concession Theory.

Thus, I agree with Larry Ribstein, who was quoted as saying that "Justice Kennedy's majority opinion and Justice Stevens' dissent represent diametrically opposed views of the corporation. ${ }^{57}$ Furthermore, the centrality of corporate theory in Citizens United is not negated by the fact that other considerations, like the listeners' rights rationale mentioned above, were also very important. As Anne Tucker explained:

In Buckley and Bellotti, the Court thwarted attempts to restrict corporate political speech on the grounds that (1) speech is money; (2) corporations contribute to the political marketplace of ideas;

53 See Avi-Yonah, supra note 39, at 1013, 1016 (quoting Hale v. Henkel, 201 U.S. 43, 76 (1906); Pembina Consol. Silver Mining \& Milling Co. v. Pennsylvania, 125 U.S. 181, 189 (1888); Cnty. of Santa Clara v. S. Pac. R.R. Co., 18 F. 385, 402-03 (C.C.D. Cal. 1883)).

54 See Padfield, The Dodd-Frank Corporation, supra note 6, at 225 ("[I]t is the artificial entity [concession] view, rather than the aggregate view, which favors regulatory solutions.").

55 See Austin v. Mich. State Chamber of Commerce, 494 U.S. 652, 679 (1990) (Scalia, J., dissenting) (“'Attention all citizens. To assure the fairness of elections by preventing disproportionate expression of the views of any single powerful group, your Government has decided that the following associations of persons shall be prohibited from speaking or writing in support of any candidate: __."').

56 Stephen Bainbridge, Citizens United v. FEC: Stevens' Pernicious Version of the Concession Theory, PROFESSORBAINBRIDGE.COM (Jan. 21, 2010, 4:05 PM), http://www.professorbainbridge.com/professorbainbridgecom/2010/01/citizens-unitedv-fec-stevens-pernicious-version-of-the-concession-theory.html.

57 Larry E. Ribstein, Citizens United v. FEC: A Roundtable Discussion, FEDERALIST SOC'Y FOR L. \& PUb. POL'Y STUd. (Feb. 3, 2010), http://www.fed-soc.org/debates/ dbtid.38/default.asp. 
(3) there is no special threat of distortion or need to equalize individual and corporate voices; (4) corporate political speech implicates freedom of association rights; and (5) concerns of compelled shareholder speech do not justify restricting corporate political speech. In subsequent cases such as Massachusetts Citizens for Life ("MCFL") and Austin, however, the Court utilized some of these same arguments to explain or validate certain restrictions on corporate political speech. Later, in Citizens United, however, the Court employed the same lines of reasoning advanced in the cases discussed below, to equalize corporate and individual speech thus expanding corporate First Amendment rights. The Court's application of these common arguments-as either an attack against or support for corporate political speech restrictions-depends on both the Court's constitutional conceptualization of corporations and its assumptions about the roles, rights, and responsibilities of corporations in our economic and legal society. ${ }^{58}$

What then becomes so striking is the majority's silence on the issue of corporate theory along with the dissent's express disavowal of any role for corporate theory. Wrote Justice Stevens: "Nothing in this analysis turns on whether the corporation is conceptualized as a grantee of a state concession,... a nexus of explicit and implicit contracts, ... a mediated hierarchy of stakeholders, ... or any other recognized model."59 I have written elsewhere that there are a number of possible explanations for this apparent contradiction, including "(1) federalism concerns; (2) a failure to appreciate the significance of corporate theory; and/or (3) a desire to avoid the appearance of imposing unconstitutional conditions on incorporation." 0

As for the federalism concerns, the Supreme Court has itself described corporations as "entities whose very existence and attributes are a product of state law." As I have written elsewhere: "Would the Court now turn around and tell states what they had created?"62 Even with the Court avoiding a direct confrontation on this issue by focusing on listeners' rights rather than corporate theory, at least some states are still nonetheless pushing back. For example, in Western Tradition Partnership, Inc. v. Attorney General, the Montana Supreme Court upheld state campaign finance laws targeting corporations despite the obvious conflict with Citizens United, ${ }^{63}$ because "unlike Citizens

58 Tucker, supra note 4, at 509.

59 Citizens United v. Fed. Election Comm'n, 130 S. Ct. 876, 971 n.72 (2010) (Stevens, J., concurring in part and dissenting in part) (citing FRANK H. EASTERBROOK \& DANIEL R. Fischel, The ECONOMIC STRUCTURE OF CORPORATE LAW 12 (1996); Blair \& Stout, supra note 10$)$ ).

60 Padfield, The Dodd-Frank Corporation, supra note 6, at 226-27 (footnotes omitted).

61 CTS Corp. v. Dynamics Corp. of America, 481 U.S. 69, 89 (1987).

62 Padfield, Citizens United and the Nexus-of-Contracts Presumption, supra note 8, at 27.

63 Western Tradition P'ship, Inc. v. Attorney Gen., 271 P.3d 1, 13 (Mont. 2011). 
United, this case concerns Montana law, Montana elections and it arises from Montana history., ${ }^{64}$

The majority and dissent in Citizens United may also have simply failed to recognize the significance of corporate theory. In other words, both sides may have felt their view of the corporation was so obviously correct as to not require further discussion. One can perhaps see this perspective in action in the very footnote in which Justice Stevens disavows any role for corporate theory. It is in this footnote that he states as a simple matter of fact that: "It is not necessary to agree on a precise theory of the corporation to agree that corporations differ from natural persons in fundamental ways, and that a legislature might therefore need to regulate them differently if it is human welfare that is the object of its concern. ${ }^{, 65}$ Yet the contention that corporations are fundamentally more than mere associations of citizens, and therefore subject to special regulation, directly implicates concession theory and is precisely the type of conceptualization of corporations that the majority rejected.

Finally, the dissent may have been motivated to avoid the issue of corporate theory for fear of setting off an "unconstitutional conditions" debate. $^{66}$ The majority asserted that: "It is rudimentary that the State cannot exact as the price of those special [corporate] advantages the forfeiture of First Amendment rights." ${ }^{, 67}$ If one understands concession theory to justify state regulation of corporations on the basis of their special status under state law, then avoiding concession theory may allow one to avoid allegations of imposing unconstitutional conditions. ${ }^{68}$

64 Id. at 6; see also id. at 11 ("The question then, is when in the last 99 years did Montana lose the power or interest sufficient to support the statute, if it ever did.”). Shortly before this Article was finalized, the United States Supreme Court summarily reversed the Montana decision. Am. Tradition P'ship v. Bullock, 132 S. Ct. 2490 (2012) (per curiam).

65 Citizens United v. Fed. Election Comm'n, 130 S. Ct. 876, 971 n.72 (2010).

66 See 16A AM. Jur. 2D Constitutional Law $\$ 395$ (1998) ("The 'doctrine of unconstitutional conditions' holds that the government ordinarily may not grant a benefit on the condition that the beneficiary surrender a constitutional right, even if the government may withhold that benefit altogether.").

67 Citizens United, 130 S. Ct. at 905 (quoting Austin v. Mich. State Chamber of Commerce, 494 U.S. 652, 680 (1990) (Scalia, J., dissenting)).

68 But cf. Michael Boardman, Constitutional Conditions: Regulating Independent Political Expenditures by Government Contractors After Citizens United, 10 FLA. ST. U. BUS. REV. 25, 4445 (2011) (" $[\mathrm{T}]$ he unconstitutional conditions doctrine... applies where the government conditions a discretionary benefit with the waiver of a fundamental right .... To satisfy the unconstitutional conditions doctrine, the restriction at issue must have a substantial nexus with the purpose of the [benefit]... At face value, restrictions on political speech by government contractors have little to do with the purpose of the contracts themselves-contracts for Lockheed Martin to build airplanes, for example, would not necessarily be substantially related to their right to engage in political speech."). See generally Darrell A.H. Miller, Guns, Inc.: Citizens United, McDonald, and the Future of Corporate Constitutional Rights, 86 N.Y.U. L. REv. 887, 929 n.278 (2011) (citing 
Regardless, the weight of the rhetoric in the opinion that I have set forth above indicates that there is indeed a silent corporate theory debate raging in Citizens United. This has led me to question whether this silent debate was unique to Citizens United or something that had been going on for some time. In order to find out, I went back and reviewed the major Supreme Court campaign finance cases relied upon in Citizens United. What follows are the results of my review.

\section{B. The Cases Leading Up to Citizens United}

The primary campaign finance cases that the Citizens United Court relied upon were (in chronological order) ${ }^{69}$ : (1) Buckley $v$. Valeo $(1976) ;^{70}$ (2) First National Bank of Boston v. Bellotti (1978); $;^{71}$ (3) Federal Election Commission v. National Right to Work Committee (1982) ("NRWC"); (4) Federal Election Commission v. Massachusetts Citizens for Life, Inc. (1986) ("MCFL"); $;^{73}$ (5) Austin v. Michigan State Chamber of Commerce (1990) $;{ }^{74}$ (6) McConnell v. Federal Election Commission (2003); ${ }^{75}$ and (7) Federal Election Commission v. Wisconsin Right to Life, Inc. (2007) ("WRTL"). ${ }^{76}$ I will briefly review each of these cases below, focusing particularly on what I see as the role corporate theory played in

Richard A. Epstein, Bargaining with the State 113-15 (1993) (discussing the protection of corporate First Amendment speech as requiring an "unconstitutional conditions" analysis); Richard A. Epstein, Citizens United v. FEC: The Constitutional Right That Big Corporations Should Have But Do Not Want, 34 HARV. J.L. \& Pub. POL'y 639, 650 (2011) (discussing the free speech benefits of the Lochner era); Larry E. Ribstein, The Constitutional Conception of the Corporation, 4 SUP. CT. ECON. REV. 95, 96 (1995) (noting that although issues related to constitutional limits on government power over corporations "generally have been examined through the broad lens of constitutional law, their resolution has in fact often depended on how the corporation is characterized"); see also id. at 105-08 (discussing and criticizing Epstein's "unconstitutional conditions" model)).

69 The six most cited cases in Citizens United in order of citation frequency were: (1) Austin v. Mich. State Chamber of Commerce, 494 U.S. 652 (1990); (2) McConnell v. Fed. Election Comm'n, 540 U.S. 93 (2003); (3) Buckley v. Valeo, 424 U.S. 1 (1976) (per curiam); (4) First Nat'l Bank of Bos. v. Bellotti, 435 U.S. 765 (1978); (5) Fed. Election Comm'n v. Wis. Right to Life, Inc., 551 U.S. 449 (2007); and (6) Fed. Election Comm'n v. Mass. Citizens for Life, Inc., 479 U.S. 238 (1986). Cf. Tucker, supra note 4, at 508 ("In applying the First Amendment to corporations, four cases are essential to understand the constitutional trajectory of the corporate political speech doctrine prior to Citizens United: Buckley v. Valeo, First National Bank of Boston v. Bellotti, FEC v. Massachusetts Citizens for Life, Inc., and Austin v. Michigan Chamber of Commerce." (footnotes omitted)).

70424 U.S. 1 (1976) (per curiam).

71435 U.S. 765 (1978) (striking down regulation of corporate political speech).

72459 U.S. 197 (1982) (upholding regulation of corporate political speech).

73479 U.S. 238 (1986) (striking down regulation of corporate political speech).

74494 U.S. 652 (1990) (upholding regulation of corporate political speech).

75540 U.S. 93 (2003) (upholding regulation of corporate political speech).

76551 U.S. 449 (2007) (striking down regulation of corporate political speech). 
each. I ultimately argue that corporate theory was relevant in five of the seven cases.

Because I want to focus on the corporate-theory aspects of these cases, it makes sense to begin at the end of the list because WRTL is one of the cases listed that does not really have much to say about corporate theory (the other is Buckley). After explaining why WRTL was nonetheless so heavily relied upon in Citizens United, I will address the remaining cases in chronological order.

\section{Federal Election Commission v. Wisconsin Right to Life, Inc.}

In WRTL, the Court "found an unconstitutional application of $\S 441 \mathrm{~b}$ where the speech was not "express advocacy or its functional equivalent.",77 The Court thus adopted "an objective 'appeal to vote' test for determining whether a communication was the functional equivalent of express advocacy." ${ }^{78}$ The reason WRTL was subsequently so hotly debated in Citizens United is that the dissent took WRTL to stand for the proposition that it was possible to deal with cases like Citizens United on an as-applied basis, and that to go on to invalidate the statute under a facial challenge was essentially to repudiate WRTL without any record to suggest the approach adopted in WRTL was a failure. ${ }^{79}$ Rather, the dissent argued that WRTL in fact not only stood for the proposition that $\S 441 \mathrm{~b}$ was constitutional, but actually made it more likely that the corporate independent expenditure provision being challenged was valid even in light of Buckley (which had held that restriction of independent expenditures by individuals violated the First Amendment, while restriction of direct contributions to candidates did not ${ }^{80}$ because it narrowed the types of speech that would be restricted under $\S 441 \mathrm{~b}$ and thus increased the likelihood that those expenditures covered by the statute post-

77 Citizens United v. Fed. Election Comm'n, 130 S. Ct. 876, 889 (2010) (quoting WRTL, 551 U.S. at 481); see also WRTL, 551 U.S. at 449 ("Section 203 of the Bipartisan Campaign Reform Act of 2002 (BCRA) makes it a federal crime for a corporation to use its general treasury funds to pay for any 'electioneering communication." (quoting 2 U.S.C. $\S 441 \mathrm{~b}(\mathrm{~b})(2)(2006)$ ).

78 Citizens United, 130 S. Ct. at 895 (quoting WRTL, 551 U.S. at 470).

79 See Citizens United, 130 S. Ct. at 933 n.5 (Stephens, J., concurring in part and dissenting in part) (“ $[T]$ he majority's argument for striking down $\S 203$ depends on its contention that the statute has proved too 'chilling' in practice—and in particular on the contention that the controlling opinion in WRTL... failed to bring sufficient clarity and 'breathing space' to this area of law.... We have no record with which to assess that claim." (citations omitted)).

80 See id. at 964-65 ("Buckley expressly contemplated that an anticorruption rationale might justify restrictions on independent expenditures at a later date, 'because it may be that, in some circumstances, "large independent expenditures pose the same dangers of actual or apparent quid pro quo arrangements as do large contributions."” (quoting WRTL, 551 U.S. at 478)). 
WRTL would facilitate corruption in a way that justified restriction under the First Amendment. ${ }^{81}$ Obviously, the Citizens United majority vehemently disagreed that WRTL constituted any sort of a roadblock on its march to invalidate the statute, or that to do so would somehow repudiate WRTL. ${ }^{82}$ However, there was no identifiable corporate theory dispute in WRTL that would be relevant to our discussion here.

\section{Buckley v. Valeo}

In Buckley, the Supreme Court held that federal statutory provisions limiting individual contributions to campaigns were constitutional, but that provisions limiting individual independent expenditures impermissibly abridged freedom of speech. ${ }^{83}$ As provided by statute:

The term "independent expenditure" means an expenditure by a person-(A) expressly advocating the election or defeat of a clearly identified candidate; and (B) that is not made in concert or cooperation with or at the request or suggestion of such candidate, the candidate's authorized political committee, or their agents, or a political party committee or its agents.

Buckley also did not directly address corporate political speech, but constitutes important precedent for Citizens United because it differentiated direct contributions from independent expenditures. ${ }^{85}$ There is thus little in

81 See id. at 967 n.66 (“[T] he notion that the 'electioneering communications' covered by $\S 203$ can breed quid pro quo corruption or the appearance of such corruption has only become more plausible since we decided McConnell... [A]fter WRTL, a corporate or union expenditure could be regulated under $\S 203$ only if everyone would understand it as an endorsement of or attack on a particular candidate for office. It does not take much imagination to perceive why this type of advocacy might be especially apt to look like or amount to a deal or a threat." (quoting WRTL, 551 U.S. at 465)).

82 Id. at 918 (Roberts, C.J., concurring) ("This case is different-not, as the dissent suggests, because the approach taken in WRTL has been deemed a 'failure,' . . . but because, in the absence of any valid narrower ground of decision, there is no way to avoid Citizens United's broader constitutional argument." (citation omitted)).

83 Id. at 901-02 (majority opinion) ("The Buckley Court explained that the potential for quid pro quo corruption distinguished direct contributions to candidates from independent expenditures. The Court emphasized that 'the independent expenditure ceiling . . . fails to serve any substantial governmental interest in stemming the reality or appearance of corruption in the electoral process,' ... because '[t] he absence of prearrangement and coordination ... alleviates the danger that expenditures will be given as a quid pro quo for improper commitments from the candidate." (citations omitted) (quoting Buckley v. Valeo, 424 U.S. 1, 47-48 (1976)).

$84 \quad 2$ U.S.C. $\$ 431$ (17) (2006).

85 See Citizens United, 130 S. Ct. at 902 (“Buckley did not consider $§ 610$ 's separate ban on corporate and union independent expenditures ....”); id. at 954 (Stevens, J., concurring in part and dissenting in part) ("Buckley famously (or infamously) distinguished direct contributions from independent expenditures, ... but its silence on corporations only reinforced the understanding that corporate expenditures could be treated differently from individual expenditures. (citation omitted)). 
the way of silent corporate theory at work in Buckley. However, the statement in the per curiam opinion that "the concept that government may restrict the speech of some elements of our society in order to enhance the relative voice of others is wholly foreign to the First Amendment," ${ }^{, 6}$ arguably becomes a tool of the aggregate view of the corporation advanced by the majority in Citizens United insofar as corporations are there deemed to be just another "element[] of our society.",7

\section{First National Bank of Boston v. Bellotti}

In Bellotti, the Court overturned a criminal statute prohibiting corporations from making expenditures to influence the outcome of a vote on any question other than questions materially affecting the business of the corporation. $^{88}$ Here, the issue of corporate political speech is front and center, yet there is again no express discussion of particular theories of the corporation. $^{89}$ Rather, we can see the silent corporate theory debate between contract and concession in some of the language used by the majority and dissent. For example, one can see the contractarian view of corporations as equivalent to other associations of citizens when the majority says: "The inherent worth of the speech in terms of its capacity for informing the public does not depend upon the identity of its source, whether corporation, association, union, or individual. ${ }^{90}$ Likewise, the

86 Buckley, 424 U.S. at 48-49. John Rawls focused on this quote in criticizing Buckley:

The Court fails to recognize the essential point that the fair value of the political liberties is required for a just political procedure, and that to insure their fair value it is necessary to prevent those with greater property and wealth, and the greater skills of organization which accompany them, from controlling the electoral process to their advantage.

John Rawls, Political Liberalism: Expanded Edition 360 (2005). See also id. at 359 ("Buckley and its sequel First National Bank [v. Bellotti] are profoundly dismaying." (citation omitted)).

87 Citizens United, 130 S. Ct. at 904; see also id. at 957 (Stevens, J., concurring in part and dissenting in part) ("The majority emphasizes Buckley's statement that 'the concept that government may restrict the speech of some elements of our society in order to enhance the relative voice of others is wholly foreign to the First Amendment.'”).

88 First Nat'l Bank of Bos. v. Bellotti, 435 U.S. 765 (1978). See also id. at 785 n.22 ("We know of no documentation of the notion that corporations are likely to share a monolithic view on an issue such as the adoption of a graduated personal income tax. Corporations, like individuals or groups, are not homogeneous." (emphasis added)). It should be noted here that it is, however, not too difficult to imagine large swaths of corporations being united in opposing all sorts of cost-imposing regulation.

89 Cf. id. at 823 n.1 (Rehnquist, J., dissenting) ("[T] he Court today affirms that the failure of [some prior] cases to draw distinctions between artificial and natural persons does not mean that no such distinctions may be drawn. The Court explicitly states that corporations may not enjoy all the political liberties of natural persons, although it fails to articulate the basis of its suggested distinction.").

$90 \quad I d$. at 777 (majority opinion). 
contractarian notion that corporations, as mere associations of citizens, start with the presumption of rights akin to other associations (with the burden of proof on those who would limit such rights), can be seen when the majority finds "no support in the First or Fourteenth Amendment, or in the decisions of this Court, for the proposition that speech that otherwise would be within the protection of the First Amendment loses that protection simply because its source is a corporation." ${ }^{91}$ Finally, the majority clearly placed itself in opposition to the concession view when it characterized as "extreme" the view that "corporations, as creatures of the State, have only those rights granted them by the State." ${ }^{92}$

The Bellotti dissent of Justice White (joined by Justice Brennan and Justice Marshall), on the other hand, employed language very much consistent with a concession view of corporations:

Corporations are artificial entities created by law for the purpose of furthering certain economic goals. In order to facilitate the achievement of such ends, special rules relating to such matters as limited liability, perpetual life, and the accumulation, distribution, and taxation of assets are normally applied to them. States have provided corporations with such attributes in order to increase their economic viability and thus strengthen the economy generally. It has long been recognized however, that the special status of corporations has placed them in a position to control vast amounts of economic power which may, if not regulated, dominate not only the economy but also the very heart of our democracy, the electoral process. ${ }^{93}$

Furthermore, the dissent of then-Justice Rehnquist quoted with approval the language from Dartmouth College that Justice Stevens cited as an example of concession theory in Citizens United: ${ }^{94}$

Early in our history, Mr. Chief Justice Marshall described the status of a corporation in the eyes of federal law: "A corporation is an artificial being, invisible, intangible, and existing only in contemplation of law. Being the mere creature of law, it possesses only those properties which the charter of creation confers upon it, either expressly, or as incidental to its very existence. These are such as are supposed best calculated to effect the object for which it was created. ${ }^{, 95}$

Thus, it is fair to read Bellotti as embodying the same type of silent corporate theory debate as I have identified in Citizens United.

Id. at 784 .

Id. at 778 n.14.

93 Id. at 809 (White, J., dissenting). See also id. ("The State need not permit its own creation to consume it.").

94 See Citizens United v. Fed. Election Comm'n, 130 S. Ct. 876, 971 n.72 (Stevens, J., concurring and dissenting) (citing Dartmouth College as example of concession theory).

95 Bellotti, 435 U.S. at 823 (Rehnquist, J., dissenting). 
Interestingly, Justice Rehnquist's stand-alone dissent in Bellotti provides arguably the sole example in these opinions of a Justice affirmatively adopting a theory of the corporation for purposes of determining the constitutional rights of corporations-though not via the express adoption of one of the traditionally recognized theories. Specifically, Justice Rehnquist relied on Justice Marshall's Dartmouth College opinion to conclude that: "Since it cannot be disputed that the mere creation of a corporation does not invest it with all the liberties enjoyed by natural persons ... our inquiry must seek to determine which constitutional protections are "incidental to its very existence.", 96 Thus, while it may be true that "a corporation's right of commercial speech... might be considered necessarily incidental to the business of a commercial corporation[, i] $t$ cannot be so readily concluded that the right of political expression is equally necessary to carry out the functions of a corporation organized for commercial purposes." ${ }^{97}$ I would argue that this is a formulation most aligned with concession theory because not only does Justice Rehnquist rely on Dartmouth College, but he also goes on to say: "I would think that any particular form of organization upon which the State confers special privileges or immunities different from those of natural persons would be subject to like regulation, whether the organization is a labor union, a partnership, a trade association, or a corporation. ${ }^{, 98}$

\section{Federal Election Commission v. National Right to Work Committee}

In $N R W C$, a unanimous Supreme Court upheld the Federal Election Campaign Act's prohibition against corporations making political contributions from their general treasury. It did so by upholding the Federal Election Commission's determination that NRWC, a political action committee, had violated the Act by soliciting contributions from persons who were not its "members."

96 Id. at 824 (citation omitted) (quoting Trs. of Dartmouth Coll. v. Woodward, 17 U.S. 518, $636(1819))$.

97 Id. at 825 (footnote omitted). Cf. id. at 827 ("One need not adopt such a restrictive view of the political liberties of business corporations to affirm the judgment of the Supreme Judicial Court in this case. That court reasoned that this Court's decisions entitling the property of a corporation to constitutional protection should be construed as recognizing the liberty of a corporation to express itself on political matters concerning that property.").

98 Id. at $826-27$.

99 Fed. Election Comm'n v. Nat'l Right to Work Comm., 459 U.S. 197, 198 n.1 (1982) ("The term 'contribution' is defined broadly, 2 U.S.C. $\$ 441 \mathrm{~b}(\mathrm{~b})(2)(\mathrm{C})$, to include any sort of transfer of money or services to various political entities, but excluded from that definition is 'the establishment, administration, and solicitation of contributions to a 
on corporate political speech. In doing so, the Court deferred to Congressional determinations regarding corruption and the dangers inherent in the corporate form. Specifically, the Court held that the stategranted "special advantages" of the corporate form justified state regulation to prevent abuse. The Court stated:

The first purpose of $\S 441 \mathrm{~b}$, [the government] states, is to ensure that substantial aggregations of wealth amassed by the special advantages which go with the corporate form of organization should not be converted into political "war chests" which could be used to incur political debts from legislators who are aided by the contributions.... The second purpose... is to protect the individuals who have paid money into a corporation .... We agree ... that these purposes are sufficient to justify the regulation at issue. ${ }^{10}$

Since this was a unanimous opinion, there is no opposing side of any corporate theory debate present. ${ }^{101}$ Nonetheless, in terms of a running theme within all the opinions I discuss herein, NRWC stands as yet another place where rhetoric consistent with concession theory is aligned with deferring to state regulation of corporate speech.

\section{Federal Election Commission v. Massachusetts Citizens for Life, Inc.}

In MCFL, the Court created an exception to the Federal Election Campaign Act for any corporation that: (1) was formed for the express purpose of promoting political ideas, and cannot engage in business activities; (2) has no shareholders or other persons affiliated so as to have a claim on its assets or earnings; and, (3) was not established by a business corporation or a labor union, and it is its policy not to accept contributions from such entities. ${ }^{102}$ The Court arguably relied on a contractarian view of the corporation in order to limit the scope of regulation. Said the majority: "Voluntary political associations do not suddenly present the specter of

separate segregated fund to be utilized for political purposes by a . . corporation without capital stock."”).

100 Id. at 207-08. See also id. at 209 ("The statute reflects a legislative judgment that the special characteristics of the corporate structure require particularly careful regulation."). Cf. id. at 210 (" $[\mathrm{T}]$ he 'differing structures and purposes' of different entities 'may require different forms of regulation in order to protect the integrity of the electoral process."' (quoting Cal. Med. Ass'n v. Fed. Election Comm'n, 453 U.S. 182, 201 (1981))).

101 Cf. Charles N. Eberhardt, Note, Integrating the Right of Association with the Bellotti Right to Hear-Federal Election Commission v. Massachusetts Citizens For Life, Inc., 72 CORNELL L. REV. 159, 176 n.110 (1986) ("Arguably, NRWC turns on the kind of expression involved: the solicitations in question resembled contributions more than expenditures and as such merited less first amendment protection under the Buckley rule.").

102 Fed. Election Comm'n v. Mass. Citizens for Life, Inc., 479 U.S. 238, 264 (1986). 
corruption merely by assuming the corporate form."103 The majority also expressly tried to recast earlier pro-regulatory opinions as not constituting referendums on the corporate form: "Regulation of corporate political activity ... has reflected concern not about use of the corporate form per se, but about the potential for unfair deployment of wealth for political purposes."

The dissent in MCFL, meanwhile, expressed disappointment at what it saw as the Court turning away from precedent that had acknowledged that the unique state-conferred benefits bestowed on corporations could justify limitations on corporate political speech. Specifically, in Federal Election Commission v. National Conservative Political Action Committee ("NCPAC"), ${ }^{105}$ the Court had declined to extend $N R W C$ s restriction of corporate political speech to Political Action Committees ("PACs"). The Court in NCPAC had said: "While in $N R W C$ we held that the compelling governmental interest in preventing corruption supported the restriction of the influence of political war chests funneled through the corporate form, in the present cases we do not believe that a similar finding is supportable.... Even assuming that Congress could fairly conclude that large-scale PACs have a sufficient tendency to corrupt, the overbreadth of $\S 9012$ (f) in these cases is so great that the section may not be upheld." ${ }^{\text {106 }}$ The MCFL dissent read NCPAC as continuing

to recognize what had been, until today, an acceptable distinction, grounded in the judgment of the political branch, between political activity by corporate actors and that by organizations not benefiting from 'the corporate shield which the State [has] granted to corporations as a form of quid pro quo' for various regulations.

Given that the state-conferred benefits argument advanced by the dissent in $M C F L$ is properly aligned with concession theory, MCFL can be read as another case wherein a silent corporate theory debate was at work.

\section{Austin v. Michigan Chamber of Commerce}

In Austin, one of the two main decisions overruled by Citizens United, the Supreme Court held that the unique state-conferred corporate structure

Id. at 263 .

Id. at 259 (footnote omitted).

470 U.S. 480 (1985).

Id. at $500-01$

479 U.S. 238, 270 (1986) (Rehnquist, J., dissenting) (quoting Citizens Against Rent Control v. Berkeley, 454 U.S. 290, 300 (1981) (Rehnquist, J., concurring)); see also id. at 267 ('In light of the 'special advantages that the State confers on the corporate form,' . . . we have considered these [anti-corruption and shareholder protection] dangers sufficient to justify restrictions on corporate political activity." (Rehnquist, J., dissenting)). 
which facilitates the amassing of large treasuries warrants limits on corporate independent expenditures. ${ }^{108}$ Said the Court:

State law grants corporations special advantages—such as limited liability, perpetual life, and favorable treatment of the accumulation and distribution of assets-that enhance their ability to attract capital and to deploy their resources in ways that maximize the return on their shareholders' investments. These state-created advantages not only allow corporations to play a dominant role in the Nation's economy, but also permit them to use "resources amassed in the economic marketplace" to obtain "an unfair advantage in the political marketplace."109

In dissent, Justice Scalia made clear that he viewed distinctions based solely on the corporate form to be insidious because corporations were just one of many types of associations of citizens: "Attention all citizens. To assure the fairness of elections by preventing disproportionate expression of the views of any single powerful group, your Government has decided that the following associations of persons shall be prohibited from speaking or writing in support of any candidate: ___.".$^{110}$ The contractarian point of view here could not be starker-corporations are literally interchangeable with any other association.

\section{McConnell v. Federal Election Commission}

Finally, in the other major case Citizens United overruled, McConnell $v$. Federal Election Commission, the Court upheld the Bipartisan Campaign Reform Act's ("BCRA") extension (via $\S 203$ ) of $\S 441 b$ 's restrictions on independent corporate expenditures. ${ }^{111}$ The majority again relied upon what can fairly be characterized as an artificial entity view: "[W]hether the state interest is compelling-is easily answered by our prior decisions regarding campaign finance regulation, which 'represent respect for the "legislative judgment that the special characteristics of the corporate

108 Austin v. Mich. State Chamber of Commerce, 494 U.S. 652 (1990). See Citizens United v. Fed. Election Comm'n, 130 S. Ct. 876, 903 (2010) ("[In Austin,] the Michigan Chamber of Commerce sought to use general treasury funds to run a newspaper ad supporting a specific candidate. Michigan law, however, prohibited corporate independent expenditures that supported or opposed any candidate for state office. A violation of the law was punishable as a felony. The Court sustained the speech prohibition.").

109 Id. at $658-59$.

$110 I d$. at 679 (Scalia, J., dissenting).

111540 U.S. 93, 132 (2003) ("BCRA's central provisions are designed to address Congress' concerns about the increasing use of soft money and issue advertising to influence federal elections.... Title II primarily prohibits corporations and labor unions from using general treasury funds for communications that are intended to, or have the effect of, influencing the outcome of federal elections."). 
structure require particularly careful regulation.","112 The dissent, meanwhile, repeated the "mere association" refrain:

In Pacific Gas E Electric Co. v. Public Utility Commission of California, ... we held unconstitutional a state effort to compel corporate speech. "The identity of the speaker," we said, "is not decisive in determining whether speech is protected. Corporations and other associations, like individuals, contribute to the 'discussion, debate, and the dissemination of information and ideas' that the First Amendment seeks to foster."

This review of the primary campaign finance cases leading up to, and relied upon in, Citizens United should make clear that an on-going debate about the nature of corporations has been central to the resolution of these cases, despite the fact that none of the opinions have expressly referenced corporate theory. So, what are we to make of this silent corporate theory debate? The answer I propose here is to call on all judges in relevant cases to expressly state their views about which corporate theory is best. This should improve the transparency of judicial opinions, as well as the accountability of judges. What follows is a brief overview of just a couple of the ways the issue of corporate theory continues to make its way before the Court post-Citizens United. The cases discussed demonstrate that, not surprisingly, the status of corporations in our modern society is not an issue that is going to go away any time soon.

\section{JUdGing CORPORATIONS POST-CITIZENS UNITED}

While the Citizens United decision cautions against betting on the corporate theory debate being addressed expressly by the Court any time soon, there should be no shortage of opportunities to challenge the Court on that point, since cases raising the question of what corporations are, and how we should best conceptualize them, are likely to continue to confront the Court with regularity. By way of example, one can examine the case of Federal Communications Commission v. ATEFT, which followed Citizens United by little more than a year and examined whether the Freedom of Information Act's protection of "personal privacy" protects the "privacy" of corporate entities. ${ }^{114}$ The Court ultimately decided the case on the basis of statutory construction: "Person' is a defined term in the statute [and expressly includes corporations]; 'personal' is not. When a statute does not define a term, we typically 'give the phrase its ordinary meaning.' .. 'Personal' ordinarily refers to individuals." However, the case simply begs the

112 Id. at 205 (quoting Fed. Election Comm'n v. Beaumont, 539 U.S. 146, 155 (2003)).

113 Id. at 257 (Scalia, J., dissenting in part) (citation omitted) (quoting Pacific Gas \& Elec. Co. v. Pub. Util. Comm'n of Cal., 475 U.S. 1, 8 (1986)).

114131 S. Ct. 1177, 1180 (2011).

115 Id. at 1182 (quoting Johnson v. United States, 130 S. Ct. 1265, 1267 (2010)). 
question of whether corporations should have personal privacy rights. Wrote Stephen Bainbridge in response to the opinion:

I agree... [with the] concern that US law confers personhood on the corporation without a coherent theory of why it does so or where the boundaries of that legal fiction are to be located. As I complained after the recent $A T \mathcal{E} T$ decision: Chief Justice Roberts could have summed up his opinion far more succinctly: "Because at least 5 of us say so." The Citizens United decision last term [also] attracted much criticism ... for holding that a corporation is a person and as such has certain constitutional rights. While I agreed with the holding, I was disturbed that the Chief Justice's majority opinion for the Supreme Court so obviously lacked a coherent theory of the nature of the corporation and, as such, also lacked a coherent theory of what legal rights the corporation possesses. The utterly specious word games that drive this opinion simply confirm that Chief Justice Roberts has failed to articulate a plausible analytical framework for this important problem. ${ }^{116}$

The Court will continue to subject itself to similar criticism so long as it declines to expressly adopt a "plausible analytical framework" in the form of a particular theory of the corporation.

Looking ahead, in Kiobel v. Royal Dutch Petroleum Co., ${ }^{117}$ the Court will soon be addressing the question whether federal courts in the United States may exercise jurisdiction over corporations pursuant to the Alien Tort Statute, which gives federal courts "original jurisdiction of any civil action by an alien for a tort only, committed in violation of the law of nations or a treaty of the United States." ${ }^{118}$ The Second Circuit, in ruling on the case below, identified the relevant issue as "the treatment of corporations as a matter of customary international law." ${ }^{119}$ This may at first blush suggest corporate theory is irrelevant because the question is not why corporations

116 Stephen Bainbridge, Schumpeter on Corporate Personhood, PROFESSORBAINBRIDGE.COM (Mar. 26, 2011, 6:43 PM), http://www.professorbainbridge.com/professorbainbridgecom/ 2011/03/schumpeter-on-corporate-personhood.html.

117621 F.3d 111 (2d Cir. 2010), cert. granted, 132 S. Ct. 472 (U.S. Oct. 17, 2011) (No. 101491). See John Bellinger, Kiobel: Supplemental Briefs on Extraterritoriality are In..., LAWFARE (Aug. 14, 2012, 10:52 PM), http://www.lawfareblog.com/2012/08/kiobelsupplemental-briefs-on-extraterritoriality-are-in/ (" $[\mathrm{I}] \mathrm{n}$ March the Supreme Court ordered the case of Kiobel $v$ Royal Dutch Petroleum to be re-briefed and reargued to address the additional question of whether the Alien Tort Statute applies to violations of international law occurring in the sovereign territory of other countries. The final supplemental briefs were filed on August 8."). 28 U.S.C. $\$ 1350$ (2006).

119 Kiobel, 621 F.3d 111, 117 n.11 (2d Cir. 2010) (emphasis omitted) ("The idea that corporations are 'persons' with duties, liabilities, and rights has a long history in American domestic law... It is an idea that continues to evolve in complex and unexpected ways. See, e.g., Citizens United v. Fed. Election Comm'n, 558 U.S. 50 (2010). The history of corporate rights and obligations under domestic law is, however, entirely irrelevant to the issue before us-namely, the treatment of corporations as a matter of customary international law." (internal citations omitted)). 
are treated a particular way under international law, but rather simply how they are in fact treated. ${ }^{120}$ Nevertheless, it may again be difficult to separate a conclusion about the scope of the statute from preconceived notions about what corporations are. For example, the Brief Amicus Curiae for the Brennan Center for Justice at NYU School of Law in Support of Petitioners ${ }^{121}$ notes the following:

In his opinion denying rehearing, a distinguished member of the panel majority below asserted that requiring multinational corporations to defend against customary international law claims in United States courts would subject them to "extort[ed]" settlements, and unjustifiably "beggar" them.... Such a canard is deeply troubling, not only because it is so clearly legislative in nature, but because it is premised on an indefensible assumption that corporations are freestanding entities less prone to great evil than the fallible human beings who constitute them. ${ }^{122}$

These are only two examples. However, given the prominent role of corporations in our modern society, it should not be too hard to convince anyone of the proposition that many other cases like these-raising the question of how we should best define corporations-will confront the Court with regularity. ${ }^{123}$

In light of this, one may ask what impact the Court expressly adopting a theory of the corporation would have. First, "bringing this debate to the surface would allow commentators and advocates to better hold judges accountable for their decisions by leaving the judges less 'wiggle room' once they have expressly aligned themselves with a particular theory, even if the

120 The question presented may ultimately extend even further beyond corporate theory. See Lyle Denniston, Kiobel to be expanded and reargued, SCOTUSBLOG (Mar. 5, 2012, 2:01 PM), http://www.scotusblog.com/2010/03/kiobel-to-be-reargued/ (noting that the Supreme Court "ordered lawyers to come back with an expanded argument on the scope of a 1789 law giving aliens a right to sue in U.S. courts. ... [S] ome of the Justices . . . questioned whether the Alien Tort Statute allowed U.S. courts to hear lawsuits for violations of international law on foreign soil").

121 Brief Amicus Curiae for the Brennan Center for Justice at NYU School of Law in Support of Petitioners at 1, Kiobel v. Royal Dutch Petroleum Co., 621 F.3d 111 (2d Cir. 2010), cert. granted, 132 S. Ct. 472 (Dec. 21, 2011) (No. 10-1491), 2011 WL 6813566.

122 Id. at 1 (quoting Kiobel v. Royal Dutch Petroleum Co., 642 F.3d 268, 270-72 (2d Cir. 2011) (opinion of Chief Judge Jacobs concurring in the denial of panel rehearing)).

123 See Padfield, The Dodd-Frank Corporation, supra note 6, at 235 ("A second timely debate that implicates corporate theory is proxy access." (citing Larry Ribstein, The securities laws and the First Amendment, TRUTH ON THE MARKET (Dec. 28, 2010), http:// truthonthemarket.com/2010/12/28/the-securities-laws-and-the-first-amendment/ (suggesting that after Citizens United the Court will be less inclined to respect distinctions that up till now have been cited to support regulation of corporate speech in areas like shareholder proposals))); id. (citing Larry Ribstein, The SEC, global warming and the First Amendment, IDEOBLOG (Jan. 29, 2010, 6:35 AM), http://busmovie.typepad.com/ ideoblog/2010/01/the-sec-global-warming-and-the-first-amendment.html (making a similar argument in terms of Citizens United's impact on the SEC's ability to require corporate disclosures on climate change)). 
debate is on-going." ${ }^{124}$ Second, even where judges are able to avoid being held accountable in this way because "the application of legal theories is more fact specific, and therefore arguably more imprecise, than their adoption," ${ }^{125}$ bringing the clash of corporate theories into the sunlight should nonetheless "serve to illuminate corporate law debates and rarefy the opposing parties." ${ }^{126}$ A further potential benefit of having judges expressly adopt particular theories of the corporation in relevant cases is that it may clarify which party has the burden of proof. For example, under the concession theory of the corporation, more of the burden would fall on those seeking to limit the state's ability to regulate its creations. ${ }^{127}$ Nonetheless, there are some valid criticisms of my proposal, and I discuss some of them next.

\section{CRITICISMS OF CORPORATE THEORY's RELEVANCE}

Some have suggested that the debate about the nature of the corporation has run its course. Stephen Bainbridge has noted that, "the debate ... is over .... Contractarians and noncontractarians no longer have much of interest to say to one another." ${ }^{128}$ However, I would submit that all of the foregoing discussion highlighting the on-going silent corporate theory debate raging in the Supreme Court's campaign finance cases suggests that contractarians and non-contractarians are still very much engaged. Of course, Bainbridge may more properly be understood to be saying that all the relevant arguments on each side have been fleshed out. Thus, what is merely going on in these cases is fulfillment of the old saw that, while everything's already been said, it has not yet been said by everyone.

124 Padfield, The Dodd-Frank Corporation, supra note 6, at 228.

125 Id.

126 Verret, supra note 25, at 315. Cf. Roger Martin, Fixing the Game: The Unintended Consequences of an Economic Theory, Huffington Post (Apr. 27, 2011, 2:40 PM), http://www.huffingtonpost.com/roger-martin/fixing-the-game-the-unint_b_854481.html ("The only way we can avoid increasingly frequent stock market meltdowns-and all the pain, suffering and economic dislocation they cause-is to explore the theories that underpin American capitalism.").

127 Compare Citizens United v. Fed. Election Comm'n, 130 S. Ct. 876, 925 (2010) (Scalia, J., concurring) ("Though faced with a constitutional text that makes no distinction between types of speakers, the dissent feels no necessity to provide even an isolated statement from the founding era to the effect that corporations are not covered, but places the burden on petitioners to bring forward statements showing that they are...."), with id. at $950 \mathrm{n} .55$ (Stevens, J., concurring in part and dissenting in part) ("Given that corporations were conceived of as artificial entities and do not have the technical capacity to 'speak,' the burden of establishing that the Framers and ratifiers understood 'the freedom of speech' to encompass corporate speech is, I believe, far heavier than the majority acknowledges.").

128 STEPhen M. BAinbridge, Corporation LAW ANd ECONOMics 31 (2002) ("[T] he debate has been fully played out."). 
Nonetheless, even here I would posit that new arguments continue to be made. For example, I have argued elsewhere that the official arrival of the too-big-to-fail corporation, which arguably made its grand entrance as a part of the financial crisis of 2008, constituted a new "data point" in the corporate theory debate. ${ }^{129}$

David Millon presents a further criticism when he argues that: "Historically, the political implications of the natural/artificial and entity/aggregate distinctions have been ambiguous, meaning different things at different times." ${ }^{, 130}$ However, Millon is arguably best understood as warning us about the complexities of corporate theory's "legitimatizing function," as opposed to disputing that there is any such function at all. ${ }^{131}$ In other words, while it may not be possible to tie a particular corporate theory to a particular result in a particular case, corporate theory may nonetheless make a particular outcome more or less likely. This view is consistent with the general alignment of "nexus-of-contracts theory with de-regulation, and concession theory with a fear of the negative consequences of deregulation." ${ }^{132}$ It is also worth noting that Millon was responding to the

129 Padfield, The Dodd-Frank Corporation, supra note 6, at 209-12 (arguing that Dodd-Frank's official recognition of the too-big-to-fail corporation undermined the majority's opinion in Citizens United because that opinion rested on a theory of the corporation that espouses a worldview wherein deregulated markets lead to efficiency, not global crisis).

130 Millon, supra note 33, at 202. See also Avi-Yonah, supra note 39, at 1022-23.

In 1926, John Dewey published an article in the Yale Law Journal in which he dismisses as irrelevant the debate among the aggregate, artificial entity, and real entity views of the corporation. These views, he explains, could be deployed to suit any purpose; and he uses examples relying on the cyclical nature of these theories. His conclusion is that theory should be abandoned for an examination of reality.

Id. (footnotes omitted) (citing John Dewey, The Historic Background of Corporate Legal Personality, 35 YaLe L.J. 655, 673 (1926)). Cf. Elizabeth Pollman, Reconceiving Corporate Personhood, 2011 UTAH L. REV. 1629, 1631 (2011) (“[A] metaphor or philosophical conception of the corporation is not helpful for the type of functional analysis that the Court should conduct. The Court should consider the purpose of the constitutional right at issue ...."). But see MORTOn J. Horwitz, The Transformation of AMERiCAN LAW 1870-1960: The CRISIS OF Legal ORTHOdOXY 106 (1992) (“[J] ohn Dewey . . could not, I believe, have demonstrated successfully that each theory of corporate personality could have equally legitimated the practices of emergent large-scale business enterprise.").

131 See Millon, supra note 33, at 241 ("[P] articular theories of the corporation are perceived to justify particular legal rules or, at a more general level, a particular approach to regulation. Although th[is] legitimation claim is a plausible interpretation...the connection between corporate theory and doctrinal and social developments is, in fact, a good deal more complex. We have yet to develop an adequate account of corporate theory's legitimating function.").

132 Padfield, The Dodd-Frank Corporation, supra note 6, at 228. See C. T. CARR, THE GENERAL PRINCIPLES OF THE LAW OF CORPORATIONS 165-73 (1905) (describing the concession theory of corporate powers as a response to fears about threats of corporate power to the sovereignty of the King); Joseph F. Morrissey, A Contractarian Defense of Corporate Regulation, 11 TRANSACTIONS: TENN. J. Bus. L. 135, 138 (2009) ("The most problematic 
arguments of the esteemed scholar Morton Horwitz, who described corporate theory as having "determinat[ive] normative implications" and playing a significant role in "the legitimation of legal doctrine and social practice." ${ }^{133}$ As Horwitz put it:

I wish to dispute [the] conclusion that particular conceptions of corporate personality were used just as easily to limit as to enhance corporate power. I hope to show that, for example, the rise of a natural entity theory of the corporation was a major factor in legitimating big business and that none of the other theoretical alternatives could provide as much sustenance to newly organized, concentrated enterprise.... [W] hen abstract conceptions are used in specific historical contexts, they do acquire more limited meanings and more specific argumentative functions.

Ultimately, we need look no further than Citizens United itself for corporate theory's relevancy. Citizens United's conclusion that political speech restrictions may not be imposed on the basis of corporate status alone would simply not have been possible under concession theory, which essentially turns on the idea that corporations are different. Rather, the result seemingly requires adoption of the contractarian view that corporations are merely associations of citizens-indistinguishable in any meaningful way from the bevy of other associations that dot the landscape. ${ }^{135}$

Finally, it can be argued that even if corporate theory is less deterministic than I suggest herein, it nonetheless serves an important legitimization function. That is to say, the average citizen hears the corporate theory story they are being told in these cases whether it is conveyed expressly or not.

portion of the nexus-of-contracts framework for me has been the normative claim that many proponents of the framework have proffered: that, because the corporation can be viewed as this bundle of privately ordered contracts, regulation is largely unnecessary and undesirable." (footnote omitted)).

133 Millon, supra note 33, at 204 (citing Morton J. Horwitz, Santa Clara Revisited: The Development of Corporate Theory, 88 W. VA. L. REV. 173, 221-22 (1985)).

134 Horwitz, supra note 130, at 68; see also DAVID A. WESTBRoOK, BETWEEN CiTIZEN AND StATE: AN INTRODUCTION TO THE CORPORATION 135 (2007) (“[A]lthough theories [of the corporation] are not determinative, from time to time and in place to place, they tend to have certain specific associations.").

135 See Tucker, supra note 4, at 520 (arguing that flawed assumptions about "principles of corporate law or their ensuing realities" led the Court to mistakenly conclude that "corporate political speech is indistinguishable from individual political speech"); see also $i d$. at 505-06 ("[T] ax treatment including the deduction of expenses and the levels of taxation ('double' for corporations), issues of criminal punishment, and the application of the commercial speech doctrine primarily to corporate speech are but a few examples of the unique treatment that corporations receive under the law." (footnote omitted)); Blair, supra note 36, at 9 ("Despite the use of the phrase 'corporate personhood' as a summary expression to indicate that a firm has the full package of corporate characteristics, all four characteristics [immortality, entity persona, limited liability, and the separation of ownership and control] actually distinguish corporations from human persons." (emphasis in original)). 
Much of the public backlash against Citizens United can be seen as a populist rejection of the idea that corporations are merely associations of citizens. ${ }^{136}$ As Thomas Joo has written in a related context:

Although the shareholder-empowerment theory points out flaws in the status quo, it does not suggest that those flaws are fatal to the legitimacy of corporations or the corporate governance regime; indeed, it suggests that marginal reforms would be sufficient to make corporations fully legitimate in conformity with the orthodox fiduciary narrative. By proposing this solution, it could be thought of as legitimating existing corporate institutions rather than challenging them.

Likewise, an honest and open debate about the role of corporate theory in cases like Citizens United could go a long way to "legitimating existing corporate institutions rather than challenging them" by better explaining the competing theories in the legal opinions that arguably turn on them. ${ }^{138}$ Put another way, at least some of the distrust of corporations evident among citizens today might be alleviated by an open and thorough discussion of corporate theory.

\section{CONCLUSION}

In this Article, I have tried to show that corporate theory played an important role not only in the Supreme Court's blockbuster Citizens United decision, but also in the significant line of campaign finance cases leading up to that decision. This is an important point because there is no express discussion of corporate theory in these cases, and in fact Justice Stevens expressly disavows any role for corporate theory in his Citizens United dissent. This disconnect between what the Justices are saying and doing implicates the transparency, accountability, and legitimacy of the Court. Rather than identify, explain, and defend their chosen theory of the corporation, the Justices ignore or deny any role for corporate theory at all. In the face of the obvious rhetorical divide between those espousing various versions of contractarianism and concession theory, the opinions start to look like modern versions of Hans Christian Andersen's “The Emperor's New Clothes." ${ }^{139}$ As Lino Graglia puts it:

\footnotetext{
136 See generally Citizens United Backlash Grows from Cali. to NYC Urging Congress to Overturn Corporate Personhood, DEMOCRACY Now (Jan. 5, 2012), http://www.democracynow.org/ 2012/1/5/citizens_united_backlash_grows_from_cali (describing the response of state and local legislatures to the Citizens United decision).

137 Thomas W. Joo, Narrative, Myth, and Morality in Corporate Legal Theory, 2009 MICH. ST. L. REV. 1091, 1105 (2009). $I d$.

139 Hans Christian Andersen, The Emperor's New Clothes, in FAiry TALEs 91 (Jackie Wullschlager ed., Tiina Nunnally trans., 2004).
} 
The Emperor's tailors were clever enough to convince him that they had made him a beautiful, though invisible, new suit of clothes. Unable to believe, or unwilling to admit, that their Emperor had been fooled, his loyal subjects also admired the clothes until an innocent child, heedless of politics and propriety, pointed out that the Emperor was naked. The Court is analogous to the Emperor's tailors in regard to its rulings of unconstitutionality. Although such rulings are obviously pure policy judgments, the Court wraps them in imaginary constitutional prohibitions, which professors of constitutional law, like the Emperor's loyal subjects, then claim to see, in the confident expectation that few others will be bold or observant enough to point out that the alleged prohibitions are entirely imaginary. ${ }^{140}$

Perhaps the public outcry in response to the Citizens United opinion will take on the role of the "innocent child" in the Hans Christian Andersen fable and help spur the Court to re-examine its avoidance and denial of the role of corporate theory in cases involving the rights and responsibilities of corporations under the Constitution. ${ }^{141}$

140 Lino A. Graglia, Originalism and the Constitution: Does Originalism Always Provide the Answer?, 34 HARV. J.L. \& PUB. POL'Y 73, 75 (2011) (footnotes omitted); see also id. at 82 ("It is only because of Justice Kennedy's vote, that the First Amendment prohibits the federal government from limiting political speech by a corporation." (citing Citizens United v. Fed. Election Comm'n, 130 S. Ct. 876, 913 (2010))).

141 Cf. Steven J. André, The Transformation of Freedom of Speech: Unsnarling the Twisted Roots of Citizens United v. FEC, 44 J. Marshall L. REv. 69, 106 n.228 (2010) ("The views of the Legal Realists notwithstanding, suffice it to say, the Court's susceptibility to the influence of public opinion is by now well accepted." (citing WILLIAM K. MUIR, JR., LAW AND Attitude Change (1984); Christopher J. Casillas, Peter K. Enns \& Patrick C. Wohlfarth, How Public Opinion Constrains The Supreme Court (Nov. 5, 2008), available at http://government.arts.cornell.edu/assets/faculty/docs/enns/Opinion_SC.pdf ("We argue that the public mood establishes a boundary that constrains-and thus directly infuences-the Court's behavior."))). 